\title{
Evaluasi Kesesuaian Lahan Ruang Terbuka Hijau terhadap RTRW Kota Bekasi
}

\author{
Bayu Prasetyo Pambudi, Mangapul Parlindungan Tambunan
}

Masuk: 20082021 / Diterima: 24102021 / Dipublikasi: 01122021

\begin{abstract}
Based on regulation No. 27 of 2007 on Spatial Planning, an area needs to have green open space with a minimum of $30 \%$ of the total available city area. Bekasi City is one of the areas currently increasing the area of green open space. Based on the Bekasi City Spatial Plan projected for 2011-2031. Bekasi City needs to provide a green open space of 6710 ha. This study aims to analyze the green open space available in Bekasi to meet the spatial planning requirements that require each region to have green open space. The data used are Landsat 8 satellite imagery, Detail Spatial Plan, and Bekasi City Regional Spatial Plan. The analytical method used is the vegetation index and overlay. The study results show that the level of vegetation distribution in Bekasi City in 2021 has decreased for the high category with an area of 6,889 ha, especially in the western part of Bekasi. The percentage of existing green open space in Bekasi City has also decreased from 2013 to 2021 by 8\% or 1,728 ha in January 2021, and the area of green open space that has been optimized for its designation for new spatial planning reaches $2.42 \%$ or an area of 525 ha with the dominant type of green open space, namely City green open space and public cemetery green open space. This percentage shows that there has not been a significant increase in the area of green open space since the Bekasi City RTRW draft was published in 2011. Overlay between the Bekasi City Detail Spatial Plan map and Bekasi City Regional Spatial Plan can help identify green open spaces built with the initial green open space design.
\end{abstract}

Key words: Green Open Space; Regional Spatial Plan; Bekasi City

Abstrak Berdasarkan regulasi Nomor 27 Tahun 2007 tentang Penataan Ruang. Sebuah wilayah perlu memiliki ruang terbuka hijau (RTH) dengan persentase minimal 30\% dari total luas kota yang tersedia. Kota Bekasi merupakan salah satu wilayah yang saat ini dalam upaya meningkatkan luas ruang terbuka hijau. berdasarkan Rencana Tata Ruang Kota Bekasi yang diproyeksikan untuk 2011-2031. Kota Bekasi perlu menyediakan ruang terbuka hijau seluas 6710 ha. Penelitian ini bertujuan untuk menganalisis ruang terbuka hijau yang tersedia di kota Bekasi agar dapat memenuhi persyaratan penataan ruang yang mewajibkan setiap wilayah memiliki ruang terbuka hijau. Data yang digunakan adalah citra satelit Landsat 8, RDTR serta RTRW Kota Bekasi. metode analisis yang digunakan adalah indeks vegetasi dan overlay. hasil penelitian menunjukan bahwa tingkat sebaran vegetasi di Kota Bekasi pada tahun 2021 mengalami penurunan untuk kategori tinggi dengan luas wilayah 6.889 ha khususnya di Bekasi bagian barat. Persentase RTH eksisting di Kota Bekasi juga mengalami penurunan dari tahun 2013 hingga 2021 sebesar $8 \%$ atau 1.728 ha pada Januari 2021 dan luas RTH yang telah dioptimalkan peruntukannya untuk penataan ruang baru mencapai $2,42 \%$ atau seluas 525 ha dengan tipe RTH yang dominan yaitu RTH Kota dan RTH TPU. Persentase ini menunjukkan bahwa belum terjadi peningkatan luas ruang terbuka hijau yang signifikan sejak rancangan RTRW Kota Bekasi diterbitkan pada tahun 2011. overlay antara peta RDTR Kota Bekasi dan RTRW Kota Bekasi dapat membantu untuk mengetahui ruang terbuka hijau yang telah dibangun dengan rancangan awal penyusunan ruang terbuka hijau.

Kata kunci: Ruang Terbuka Hijau; RTRW; Kota Bekasi

This is an open access article under the CC BY-SA license.

Copyright $\odot 2021$ by Author. Published by Universitas Pendidikan Ganesha.

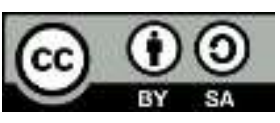




\section{Pendahuluan}

Ruang terbuka hijau (RTH) merupakan suatu area yang memanjang atau mengelompok dimana penggunaanya oleh masyarakat bersifat terbuka, tempat untuk tumbuh berkembangnya tanaman baik secara alamiah maupun sengaja untuk ditanam. RTH dapat diklasifikasikan berdasarkan kepemilikan, fungsi, pola serta strukturnya. Berdasarkan pasal 29 UU No 26 tahun 2007 tentang penataan ruang, dijelaskan bahwa RTH dibedakan

berdasarkan kepemilikannya, RTH publik dan RTH privat dengan persentase $20 \%$ merupakan RTH publik dan RTH privat $10 \%$, hal ini menjadikan syarat bahwa suatu wilayah harus memiliki RTH dengan persentase $30 \%$ dari total luas wilayah administrasi yang ada.

RTH memiliki banyak fungsi, khususnya terhadap lingkungan. Menurut Direktorat Penataaan Bangunan dan Lingkungan, fungsi RTH yaitu untuk mengurangi polutan, menghasilkan oksigen, memperbaiki kualitas iklim, mengontrol radiasi yang dihasilkan dari matahari, meningkatkan nilai estetika serta sebagai tempat terjadinya interaksi sosial.

Keberadaan RTH sangat diperlukan untuk wilayah perkotaan. Adanya RTH diharapkan dapat menanggulangi permasalahan kualitas lingkungan yang disebabkan oleh aktivitas perkotaan. RTH memiliki peran sebagai pengatur iklim mikro perkotaan yang dapat menurunkan suhu

${ }^{1}$ Bayu Prasetyo Pambudi, ${ }^{1}$ Mangapul Parlindungan Tambunan ${ }^{1}$ Universitas Indonesia, Indonesia

bayu.prasetyo01@ui.ac.id permukaan secara langsung dan berpengaruh terhadap sebaran suhu udara dan dapat meningkatkan kualitas hidup masyarakat (Ahmad et al., 2012).

Meskipun sudah diatur oleh undang-undang dan memiliki banyak manfaat, namun tidak semua kota mampu menyediakan RTH yang memadai, salah satunya yaitu Kota Bekasi. Kota Bekasi merupakan salah satu kota metropolitan dengan kepadatan penduduk yang cukup tinggi. Jumlah penduduk Kota Bekasi saat ini mencapai 3.084 juta pada tahun 2020 (BPS, 2020). selain itu, lokasi Kota Bekasi berbatasan langsung dengan Provinsi DKI Jakarta menjadikan aktivitas di Kota Bekasi berjalan dengan sangat padat. Saat ini Kota Bekasi sudah berkembang menjadi tempat tinggal masyarakat urban serta sebagai lokasi industri. Meningkatnya arus urbanisasi di Kota Bekasi menjadikan fenomena alih pungsi lahan menjadi lahan pemukiman serta jasa dan komersil menjadi tidak terhindarkan. Hal ini menyebabkan terjadinya fenomena alih fungsi lahan dari lahan hijau menjadi lahan terbangun, menurut Ramadhan (2018) Kota Bekasi yang memiliki luas wilayah sekitar $210.49 \mathrm{~km}^{2}$ harus memiliki persentase RTH sebesar $30 \%$ dari total luas wilayah atau sekitar $63.147 \mathrm{~km}^{2}$, dimana sekitar $20 \%$ merupakan lahan RTH yang disediakan oleh pemerintah sementara $10 \%$ disediakan oleh swasta maupun masyarakat. Walaupun begitu alih fungsi lahan RTH menjadi lahan terbangun di wilayah Kota Bekasi tidak terhindarkan seiring dengan bertambahnya jumlah penduduk Kota Bekasi serta meningkatnya frekuensi aktivitas masyarakat. 
Berdasarkan data yang dilansir dari kompas.com, luas lahan terbangun di wilayah Kota Bekasi pada tahun 2013 mencapai 59,6\% dari total keseluruha wilayah Kota Bekasi, 47\% di antaranya merupakan kawasan perumahan (Mantalean, 2020). Sementara itu, penelitian yang dilakukan pada tahun 2016 menjelaskan bahwa RTH di Kota Bekasi baru mencapai 16\%, hal tersebut memberikan selisih $14 \%$ dari syarat yang diwajibkan (Cahya et al., 2016).

Hal tersebut semakin meningkat dengan bertambahnya jumlah penerbitan IMB yang mencapai 7.000 lembar per tahun. Sebagai contoh, pada tahun 2014, Pemerintah Kota Bekasi menerbitkan 7.000 IMB. Jumlah tersebut semakin meningkat menjadi 8.012 IMB pada tahun 2018. Hal ini pada akhirnya berdampak pada menyusutnya cakupan lahan basah yang berperan sebagai areal tangkap air di Kota Bekasi. Pada tahun 2018, persentase lahan basah di Kota Bekasi hanya mencapai $2.11 \%$ dari total luas wilayah, hal ini tentunya berdampak pada persentase RTH Kota Bekasi yang tersisa $5,26 \%$ dari total luas Kota Bekasi, tentunya ini belum memenuhi syarat bahwa setiap daerah harus mampu menyediakan 30\% ruang hijau dari total luas wilayah di daerahnya. Selain itu, pada aspek lainnya, penelitian yang dilakukan oleh Ramadhan (2018) menggunakan analisis Driving Force Pressure State Impact Response (DPSIR) menunjukan bahwa permasalahan RTH di Kota Bekasi tidak hanya berfokus pada aspek alih fungsi lahan, namun persepsi masyarakat Kota Bekasi yang masih negatif merupakan permasalahan lainnya yang perlu diselesaikan. Aspek pengetahuan masyarakat terhadap RTH cukup baik, namun aspek afektif (sikap) menunjukan negatif, menandakan bahwa belum ada kesadaran dari masyarakat untuk menjaga dan melestarikan RTH yang berada di Kota Bekasi. dari hal tersebut maka dapat dijelaskan bahwa permasalahan ruang hijau atau RTH di Indonesia tidak hanya terpaku pada alih fungsi lahan hijau menuju lahan terbangun, namun aspek sosial masyarakat sebagai pihak yang memanfaatkan ruang hijau justru tidak menjaga kelestarian dari ruang hijau yang tersedia. Oleh karena itu, diperlukan kajian dengan sudut pandang ekologi sebagai ilmu yang membahas interaksi manusia dengan lingkungannya dalam membahas perilaku masyarakat yang belum dapat menjaga dan melestarikan fasilitas ruang hijau yang tersedia.

Penelitian ini mengkaji bagaimana perkembangan RTH di Kota Bekasi saat ini disesuaikan dengan Rencana Tata Ruang Wilayah Kota Bekasi Tahun 2011-2031 dengan studi kasus berdasarkan perkembangan terakhir yaitu pada Januari 2021, tujuan dari penelitian ini adalah untuk menganalisis kesesuaian lahan RTH yang tersedia di Kota Bekasi saat ini dengan rancangan RTRW Kota Bekasi disusun pada tahun 2011.

\section{Metode}

Penelitian dilaksanakan di Kota Bekasi dengan tujuan untuk menganalisis kesesuaian lahan RTH di Kota Bekasi. Teknik pengumpulan data dilakukan melalui pengumpulan studi 
Evaluasi Kesesuaian Lahan Ruang Terbuka Hijau terhadap RTRW Kota Bekasi/Bayu Prasetyo Pambudi, Mangapul Parlindungan Tambunan

literatur yang berasal dari data spasial terkait RTH dan Rencana Tata Ruang Wilayah Kota Bekasi. Referensi terkait berasal dari penelitian sebelumnya yang mengkaji ketersediaan RTH

Analisis data dilakukan dengan menggunakan Arc Gis 10.4 untuk melakukan proses olahan data sehingga nantinya dapat menghasilkan sumber data spasial yang diperlukan. Alur pikir penelitian ini dapat dilihat Gambar 1.

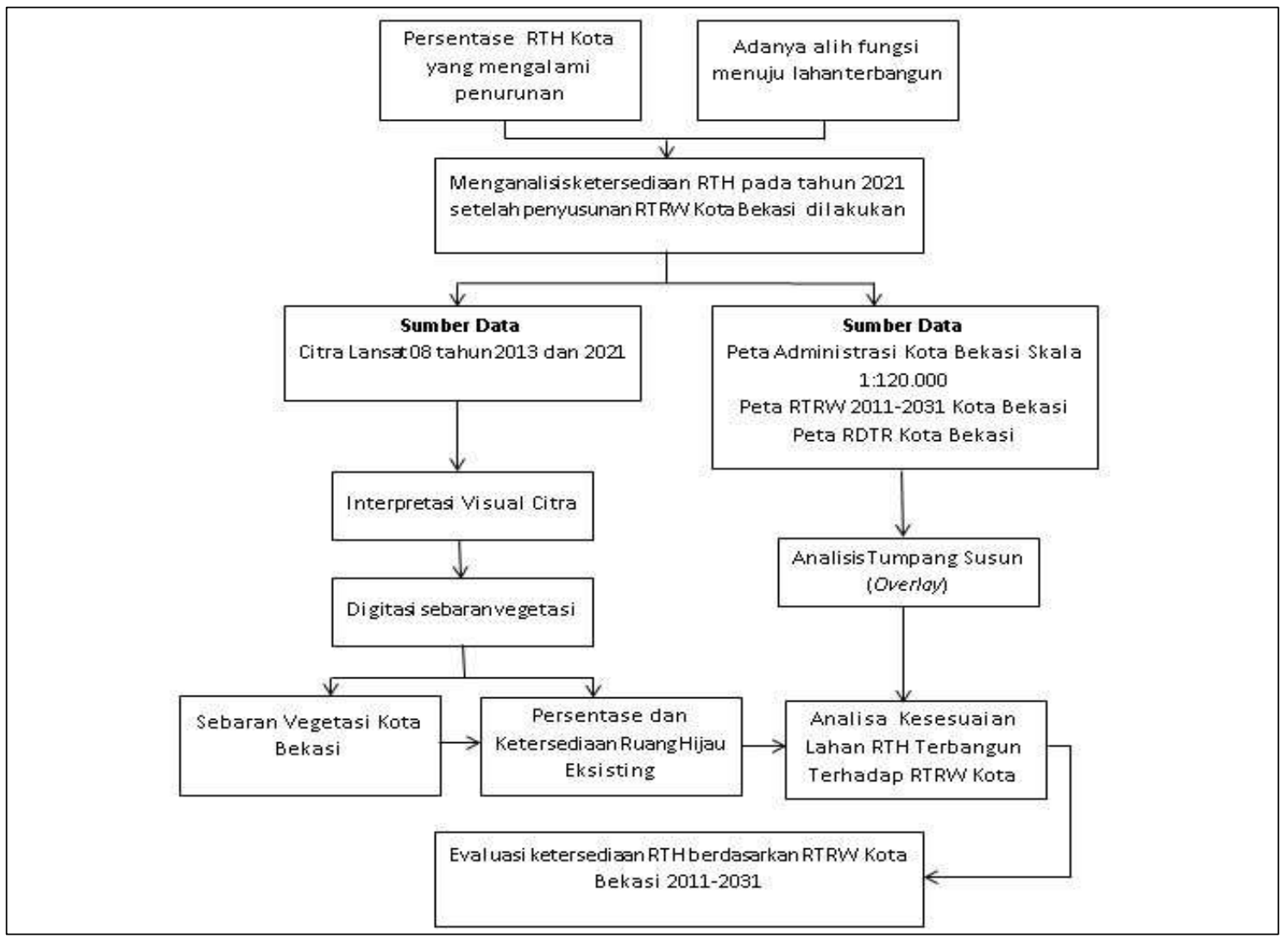

Gambar 1. Alur Pikir Penelitian

Variabel yang digunakan dalam penelitian ini adalah sebaran kerapatan vegetasi dan persentase serta luas ruang hijau eksisting. Sebaran kerapatan vegetasi diperlukan untuk mengetahui tingkat kerapatan vegetasi di Kota Bekasi sementara persentase serta luas ruang hijau eksisting untuk mengetahui ketersediaan ruang hijau di Kota Bekasi yang dapat dioptimalkan sebagai RTH berdasarkan klasifikasi RTH yang terdapat pada Rencana Detail Tata Ruang (RDTR) Kota Bekasi berdasarkan data citra terakhir yaitu pada pengambilan tahun Januari 2021.

Data yang diperlukan dalam analisis data spasial adalah citra satelit landsat 8 yang diperoleh dari earth explorer dengan resolusi spasial $30 \mathrm{~m}$ x $30 \mathrm{~m}$ dan mampu merekam dalam 7 saluran spektral (Tjaturahono, 2013). Citra satelit landsat 8 dirancang dengan membawa sensor citra OLI (Operational Land Imager) yang memiliki 1 kanal inframerah dan 7 kanal reflektif. Sensor pencitra OLI memiliki 
kanal-kanal spektral yang memiliki kesamaan dengan sensor ETM+ dari landsat 8, namun sendor pencitra OLI memiliki kanal-kanal ataupun saluran citra yang baru (Sitanggang, 2011).

Setiap saluran citra tersebut memiliki tingkat kepekaan terhadap objek spectral yang dikaji pada gelombang tertentu dan hal ini menyebabkan perbedaan variasi pada setiap citra. Yunhao et al (2006) menjelaskan bahwa resolusi spasial yang tinggi dari penginderaan jauh diperlukan dalam membedakan tutupan vegetasi pada daerah yang memiliki tutupan lahan heterogen sehingga kesalahan interpretasi dapat diminalisir. Hal ini juga didukung oleh Febrianti \& Sofan ( 2014) yang menyatakan bahwa citra dengan resolusi spasial yang tinggi sangat diperlukan untuk analisis identifikasi RTH di kawasan perkotaan dengan tingkat keragaman penutup lahan yang heterogen dengan luasan yang sempit. Analisis yang dihasilkan nantinya berupa Normalized Difference Vegetation Index (NDVI) yang selanjutnya digunakan untuk mengetahui tingkat kerapatan lahan ruang terbuka hijau.

$$
\text { Penelitian Noviyanti \& }
$$

Roychansyah (2019) membuktikan bahwa perubahan pola sebaran vegetasi dapat diamati dari hasil olahan citra landsat menggunakan metode NDVI. Selain itu, terdapat beberapa penelitian terdahulu berkaitan dengan RTH menggunakan analisis NDVI untuk mengetahui sebaran vegetasi yang selanjutnya diolah untuk mengetahui ketersediaan RTH seperti Phanderson et al (2018), Nailufar (2018) dan Hatulesila et al (2019)
WHO (2016) menyebutkan bahwa salah satu indikator dalam mengukur ketersediaan ruang terbuka hijau adalah dengan menggunakan NDVI untuk membandingkan tingkat kehijauan vegetasi pada tumbuhan pada suatu wilayah yang sumber datanya berasal dari citra satelit. NDVI dapat digunakan sebagai standar yang mampu membandingkan citra satelit dengan kerapatan, biomasa dan tingkat kehijauan (Balqis et al., 2018). Nilai NDVI dihasilkan dari perbedaan antara penyerapan radiasi pada panal merah serta reflektansi maksimum di kanal spektral infra merah. Dalam landsat 8, band yang digunakan adalah band 4 dan band 5 untuk mengetahui sebaran kerapatan. Band 4 merupakan hasil dari pigmen klorofil. Reflektansi maksimum di kanal spektral infra merah adalah band 5 (Tucker, 1979), Dengan demikian formula rumus yang digunakan adalah sebagai berikut:

$$
N D V I=\frac{(N I R-R E D)}{(N I R+R E D)}
$$

Keterangan:

NDVI : Normalized Difference Vegetation Index

NIR : Near Infared Band (Band 5)

RED : Red Band (Band 4)

Hasil klasifikasi persentase tingkat NDVI nantinya akan dibagi menjadi lima kelas setelah sebelumnya dilakukan perhitungan luas wilayah dari masing-masing kerapatan vegetasi dengan perangkat lunak Arc Gis yang ditampilkan pada Tabel 1. 
Evaluasi Kesesuaian Lahan Ruang Terbuka Hijau terhadap RTRW Kota Bekasi/Bayu Prasetyo Pambudi, Mangapul Parlindungan Tambunan

Tabel 1. Klasifikasi NDVI

\begin{tabular}{ccc}
\hline Kelas & Nilai NDVI & Tingkat Kehijauan \\
\hline 1 & $-1<\mathrm{NDVI}<-0.03$ & Lahan Tidak Bervegetasi \\
2 & $-0.03<\mathrm{NDVI}<0.15$ & Kehijauan Sangat Rendah \\
3 & $0.15<\mathrm{NFVI}<0.25$ & Kehijauan Rendah \\
4 & $0.25<\mathrm{NDVI}<0.35$ & Kehijauan Sedang \\
5 & $0.35<\mathrm{NDVI}<1$ & Kehijauan Tinggi \\
\hline
\end{tabular}

Sumber: Wahyunto (2003)

\section{Hasil dan Pembahasan}

Rancangan tata ruang wilayah

Kota Bekasi disusun berdasarkan Peraturan Daerah Kota Bekasi No 13 Tahun 2011 tentang Rencana Tata Ruang Wilayah Kota Bekasi Tahun 2011-2031 dengan tujuan untuk mewujudkan Kota Bekasi sebagai tempat hunian serta usaha kreatif untuk masyarakat yang nyaman dengan peningkatan kualitas lingkungan hidup yang berkelanjutan. Pada rancangan RTRW Kota Bekasi 2011-2031 yang disusun pada tahun 2011 dan ditampilkan pada Tabel 2, luas RTH yang tersedia saat itu adalah 98 ha dari total luas wilayah Kota Bekasi yang mencapai 21.050 ha atau $215 \mathrm{~km}^{2}$. Penggunaan lahan tertinggi didapati oleh pemukiman kelas padat dengan luas 8006 ha atau $80.06 \mathrm{~km}^{2}$.

Tabel 2. Rancangan kebutuhan lahan RTRW Kota Bekasi

\begin{tabular}{|c|c|c|c|}
\hline No & Penggunaan Lahan & Luas (ha) & Persentase (\%) \\
\hline 1 & Industri & 1253.3 & 5.80 \\
\hline 2 & Kawasan Perlindungan Setempat & 1419 & 6.56 \\
\hline 3 & Kawasan Pertambangan & 142.5 & 0.66 \\
\hline 4 & Pemerintahan & 48.5 & 0.22 \\
\hline 5 & Perdagangan dan Jasa & 4169.1 & 19.28 \\
\hline 6 & Perumahan Kepadatan Rendah & 1413.2 & 6.54 \\
\hline 7 & Perumahan Kepadatan Sedang & 4867.9 & 22.51 \\
\hline 8 & Perumahan Kepadatan Tinggi & 8006.1 & 37.03 \\
\hline 9 & Potensi Tampungan Air & 84.3 & 0.39 \\
\hline 10 & Ruang Terbuka Hijau & 98.2 & 0.45 \\
\hline 11 & Situ & 18.5 & 0.09 \\
\hline 12 & TPA & 102.5 & 0.47 \\
\hline \multicolumn{2}{|r|}{ Total } & 21623.1 & 100 \\
\hline
\end{tabular}

Sumber: Dokumentasi Pribadi (2021)

Berdasarkan Tabel 2, terlihat bahwa persentase penggunaan lahan tertinggi didominasi oleh kawasan pemukiman dengan kategori perumahan kepadatan tinggi serta perumahan kepadatan sedang, sementara itu terdapat kawasan perdagangan dan jasa dengan persentase $19.68 \%$ Rancangan RTRW Kota Bekasi juga menunjukan bahwa persentase RTH Kota Bekasi saat itu baru sekitar $0.45 \%$ dengan jenis sempadan sungai dan taman kota ketika rancangan ini disusun pada 
tahun 2011, namun di tahun 2012, ketersediaan RTH di Kota Bekasi meningkat sebesar 15\% (Bayu et al, 2015) dengan sebaran terluas terdapat di Kecamatan Rawalumbu dan Bekasi Selatan (Sitorus et al, 2012). Hal tersebut menunjukan bahwa persyaratan yang diajukan terkait persentase RTH di Kota Bekasi pasca penyusunan RTRW mengalami peningkatan walaupun belum dapat memenuhi syarat yang diajukan yaitu $30 \%$ dari total luas wilayah yang ada.

\section{Klasifikasi Ruang Terbuka Hijau dan Jenis Vegetasi di Kota Bekasi}

Pada rancangan pola ruang wilayah kota bagian rencana pengembangan kawasan lindung, dijelaskan bahwa pada berdasarkan Pasal 15 ayat 1 kawasan lindung terbagi menjadi dua, yaitu Kawasan Perlindungan Setempat dan kawasan RTH Kota.

Kawasan perlindungan setempat dikelola dengan rencana pengelolaan, rehabilitasi serta memperbanyak tanaman pohon dan melarang aktivitas penggunaan lahan di sepanjang jalur hijau sesuai dengan aturan yang berlaku. RTH kota disesuaikan dengan Pasal 16 huruf $b$ yaitu RTH Kota terdiri dari:

- Kawasan Penyangga;

- Hutan Kota;

- Taman Kota;

- Taman Lingkungan;

- Taman Rekreasi;

- TPU;

- Lapangan Terbuka;

- Pulau Jalan;

- Taman di sekitar halaman gedung;

- Ruang hijau persil;
- Lahan pekarangan pribadi;

- Sempadan jalan;

- Sempadan sungai.

Berdasarkan pasal 18 huruf $b$ dijelaskan bahwa pengembangan RTH di Kota Bekasi harus mencapai proporsi $30 \%$ dari luas wilayah yaitu sekitar 6.700 ha terdiri dari:

- RTH Publik dengan luas kurang lebih $4.120 \mathrm{Ha}(20 \%)$;

- RTH Privat dengan luas kuran lebih $2.105(10 \%)$

Pada kaitan fungsi vegetasi terhadap RTH. Vegetasi yang terdapat di wilayah perkotaan mampu mempengaruhi radiasi sinar matahari terhadap kenyamanan dari wilayah perkotaan, khususnya pada daerah tropis yang cukup tinggi akan berpengaruh terhadap kenyamanan masyarakat di wilayah tersebut. penelitian yang dilakukan oleh Cahya et al (2016) menjelaskan bahwa semakin tinggi kerapatan vegetasi dan bervariasinya jenis vegetasi di wilayah tersebut maka temperatur udara di wilayah tesebut akan semakin rendah dan kelembapan akan semakin tinggi. Hal ini diperjelas kembali oleh Maysitha \& Ariffin (2019) bahwa terdapat beberapa jenis vegetasi yang mempengaruhi aspek ekologi perkotaan seperti Pohon Mangga, Ketapang Kencana, Pohon Bintaro dan Pohon Beringin yang merupakan vegetasi dominan di Kota Bekasi. 


\section{Sebaran Vegetasi di Kota Bekasi}

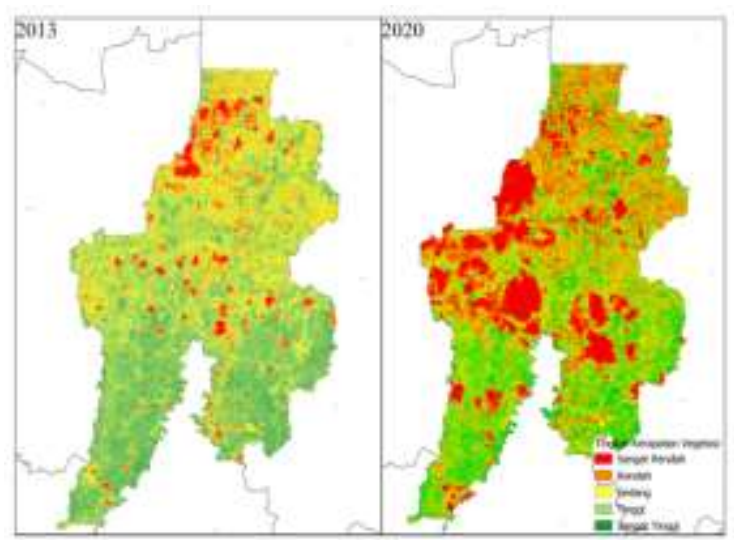

Gambar 2. Sebaran Kerapatan Vegetasi Kota Bekasi

Penggunaan citra landsat 08 yang diolah dengan menggunakan metode NDVI dilakukan untuk mengetahui sebaran dari ketersediaan vegetasi di wilayah Kota Bekasi pada tahun 2013 dan 2020. Berdasarkan Gambar 2, terlihat bahwa terjadi penurunan luas lahan dengan kategori tinggi pada tahun 2020 khususnya di wilayah Bekasi bagian barat, hal ini dapat dilihat dengan banyaknya wilayah area dengan kategori sangat rendah dan rendah yang terdapat pada kerapatan vegetasi tahun 2020, berbeda dengan tahun 2013 dimana sebaran vegetasi di Kota bekasi didominasi oleh kategori sedang dan tinggi. Hal ini menunjukan bahwa penggunaan lahan semakin meningkat di tahun 2020 dan hijau tersebut berdampak pada berkurangnya tingkat kerapatan vegetasi di wilayah Kota Bekasi pada tahun 2020.

Berdasarkan sebaran vegetasi yang ditampilkan pada Gambar 2, maka dilakukan olahan selanjutnya untuk mengetahui luas dan persentase vegetasi di Kota Bekasi pada tahun 2013 dan tahun 2020. Berdasarkan Tabel 3 yang menampilkan luas dan persentase sebaran vegetasi di Kota Bekasi, dapat dijelaskan bahwa bahwa pengambilan citra pata tahun 2013, areal dengan klasifikasi sebaran vegetasi tinggi memiliki luas 11044 ha atau $51 \%$ dari total luas wilayah, klasifikasi tinggi dengan 5414 ha. rendah 3628 ha, sangat rendah 1243 ha dan lahan tidak bervegetasi dengan luas 28 hektar atau $0.1 \%$. Sementara itu, pada citra landsat terakhir bulan Agustus 2020, terjadi penurunan luas lahan dari klasifikasi sangat tinggi mencapai 6882 ha atau 32\% dan tinggi dengan 3880 ha, pada klasifikasi sangat rendah, rendah dan tinggi mengalami peningkatan luas lahan sebesar 10652 ha.

Tabel 3. Luas dan persentase sebaran vegetasi di Kota Bekasi

\begin{tabular}{ccccc}
\hline \multirow{2}{*}{ Klasifikasi } & \multicolumn{2}{c}{ Sebaran Vegetasi } & \multicolumn{2}{c}{2021} \\
& Luas (ha) & $\%$ & Luas (ha) & \% \\
\hline Tidak bervegetasi & 28.22 & 0.1 & 769.48 & 3.6 \\
sangat rendah & 1243.87 & 5.8 & 4070.72 & 19.0 \\
Rendah & 3682.19 & 17.2 & 5811.93 & 27.1 \\
Sedang & 5415.02 & 25.3 & 3880.03 & 18.1 \\
Tinggi & 11044.68 & 51.6 & 6889.26 & 32.2 \\
Total & 21413.98 & 100 & 21421.42 & 100
\end{tabular}

Sumber: Dokumentasi Pribadi (2021) 
Perhitungan Luas dan Persentase Ruang Hijau Eksisting di Kota Bekasi

Analisis data terkait ketersediaan ruang hijau eksisting di Kota Bekasi menggunakan data raster yang diolah sebelumnya pada olahan data kerapatan vegetasi menggunakan metode NDVI dengan pengubahan klasifikasi kelas menjadi lahan vegetasi dan non vegetasi ditampilkan pada Gambar 3.

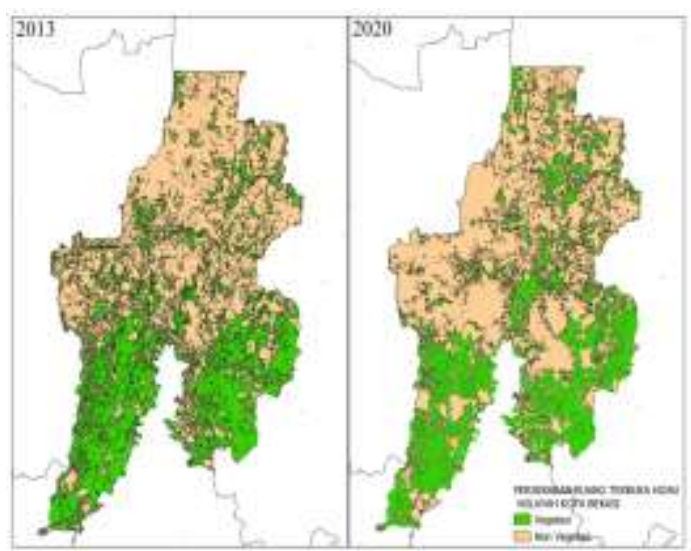

Gambar 3. Persebaran Ruang Hijau di Kota Bekasi

Berdasarkan hasil olahan data yang ditampilkan pada Gambar 3. Terlihat bahwa wilayah Kota Bekasi bagian barat dan utara mengalami peningkatan lahan non vegetasi. Pada tahun 2013, lahan non vegetasi memliki luas 12736 atau $59.5 \%$ dan meningkat menjadi 14472 atau $67.6 \%$ di tahun 2021. Sementara itu pada lahan vegetasi mengalami penurunan luas lahan sebesar 1728 ha dengan persentase $32.4 \%$ pada tabel 2020 (lihat Tabel 4).

Dari persentase tersebut menunjukan bahwa ketersediaan lahan ruang hijau eksisting yang terdapat di kota bekasi pada tahun 2020 mencapai
$32.4 \%$ dari total luas wilayah Kota Bekasi.

Tabel 4. Luas dan persentase kerapatan ruang hijau eksisting di Kota Bekasi

\begin{tabular}{lcccc}
\hline $\begin{array}{c}\text { Tutupan } \\
\text { Lahan }\end{array}$ & $\begin{array}{c}c \\
\text { Luas } \\
\text { (ha) }\end{array}$ & $\%$ & $\begin{array}{c}2013 \\
\text { Luas } \\
\text { (ha) }\end{array}$ & $\%$ \\
\hline Non Vegetasi & 12736 & 59.5 & 14472 & 67.6 \\
Vegetasi & 8677 & 40.4 & 6949 & 32.4 \\
Total & 21413 & 100 & 21421 & 100 \\
\hline
\end{tabular}

Sumber: Dokumentasi Pribadi (2021)

\section{Kesesuaian Lahan RTH Terhadap RTRW Kota Bekasi}

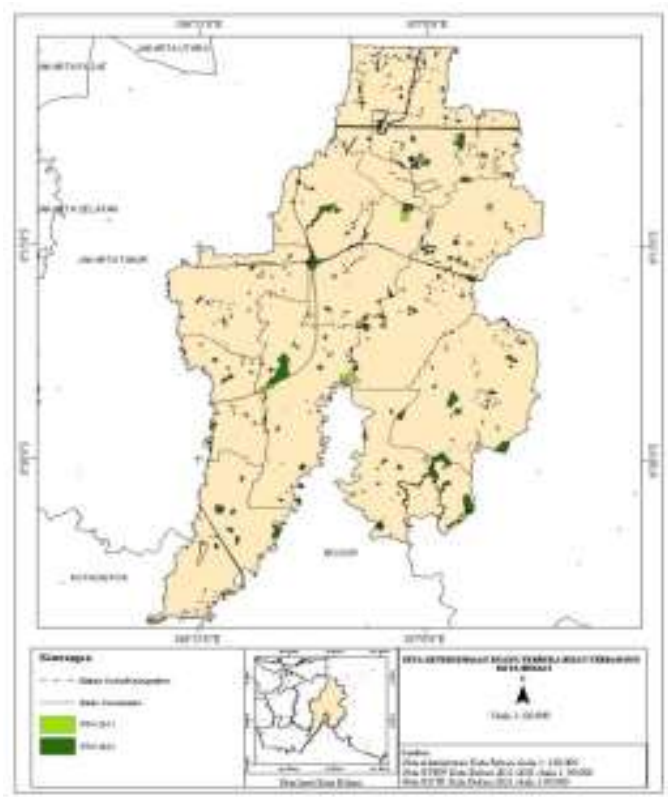

Gambar 4. Peta kesesuaian lahan RTH terbangun Kota Bekasi

Peta kesesuaian lahan RTH terbangun dibuat Berdasarkan peta Rencana Detail Tata Ruang (RDTR) Kota Bekasi yang diunduh melalui gistaru.atrbpn.go.id dan memuat rancangan secara terperinci mengenai tata ruang wilayah kabupaten/kota yang dilengkapi dengan peraturan zonasi kabupaten/kota yaitu Ketentuan Peraturan Pemerintah Nomor 15 Tahun 2010 Pasal 59 tentang 
Penyelenggaraan Penataan Ruang serta peta Rencana Tata Ruang Wilayah (RTRW) Kota Bekasi tahun 2011, Sebaran RTH di Kota Bekasi terbagi menjadi beberapa jenis, yaitu RTH Jalur Hijau, RTH Kota, RTH Sabuk Hijau, RTH Taman Kecamatan dan RTH Taman Kelurahan. Pada hasil analisis yang ditampilkan pada Gambar 4 menunjukan bahwa jenis RTH Kota memiliki luas tertinggi yaitu 256 ha serta diikuti dengan RTH TPU dengan luas 114 ha, setelah itu terdapat RTH Kecamatan (76 ha), RTH Kelurahan (36 ha), RTH Sabuk Hijau (22 ha) dan RTH Jalur Hijau (20 ha). Walaupun begitu, persentase dari ruang hijau yang sudah dioptimalkan sebagai RTH sesuai dengan klasifikasi kawasan lindung dalam Peraturan Daerah Kota Bekasi No 13 Tahun 2011-2031 baru mencapai $2.43 \%$ atau 525 ha pada tahun Januari 2021, terdapat peningkatan luas RTH yang terdapat dalam RTRW Kota Bekasi sebesar $0.45 \%$ di tahun 2011, namun persentase tersebut belum dapat memenuhi persyaratan dalam UndangUndang No 26 Tahun 2007 tentang Penataan Ruang yang mewajibkan sebuah wilayah harus mampu menyediakan lahan RTH sebesar 30\% dari total luas wilayah yang tersedia.

\section{Penutup}

Hasil pembahasan menunjukan bahwa citra landsat 8 yang dianalisis menggunakan NDVI dapat digunakan untuk mengetahui sebaran vegetasi di wilayah Kota Bekasi. Sebaran vegetasi tersebut dapat dioptimalkan sebagai lahan ruang terbuka hijau yang dibangun sesuai dengan klasifikasi RTH menurut pasal 16 yang terdapat dalam Perda Kota Bekasi no 16 Tahun 2011.

Berdasarkan hasil pembahasan, dapat disimpulkan bahwa sejak penyusunan RTRW Kota Bekasi pada tahun 2011, Persentase luas RTH terbangun di Kota Bekasi belum mengalami peningkatan yang signifikan. Cakupan areal RTH terbangun sebesar 525 ha atau $2.43 \%$ dari luas wilayah di tahun 2020 belum dapat memenuhi persyaratan yang diajukan oleh pemerintah pusat bahwa syarat penyediaan RTH sebesar $30 \%$ dari total luas wilayah Kota Bekasi.

Alih fungsi lahan terbuka dan pemanfaatannya sebagai lahan terbangun menjadi salah satu alasan dari berkurangnya cakupan areal RTH di Kota Bekasi. Pada tahun 2021, direncanakan bahwa luas wilayah di Kota Bekasi yang dibutuhkan untuk pengembangan kawasan pemukiman yaitu $82.24 \mathrm{~km}^{2}$ (Bagus W.2021), hal ini dapat berpotensi terjadinya perubahan luas areal RTH di Kota Bekasi. Walaupun begitu, ketersediaan ruang hijau eksisting di Kota Bekasi yang mencapai 6949 ha dapat dioptimalkan peruntukannya sebagai RTH terbangun sesuai dengan pedoman pemanfaatan ruang terbuka pasal 15 ayat 1 tentang kawasan lindung yang dapat mengkategorikan ruang hijau eksisting sebagai RTH Kota.

Dalam perkembangan selanjutnya, rekomendasi untuk penelitian berikutnya diperlukan untuk mengoptimalkan penelitian mengenai pemanfaatan RTH di Kota Bekasi. Kajian terkait RTH eksisting yang tersedia di tahun 2021 terhadap iklim mikro Kota Bekasi diperlukan untuk mengetahui efektifitas dari ruang hijau 
terhadap peningkatan kualitas suhu. Selain itu, persepsi masyarakat terhadap RTH eksisting seperti taman kota dan hutan kota di tahun 2021 diperlukan untuk mengetahui kondisi kelayakan sarana-prasarana RTH yang tersedia mengingat taman kota dan hutan kota merupakan bagian dari ruang publik aktif dimana terdapat unsur-unsur kegiatan manusia yang beraktivitas di ruang publik tersebut (Muta'ali, L. \& Purnamasari, S, 2012)

\section{Ucapan Terima Kasih}

Ucapan terima kasih ditujukan kepada Dr. Mangapul Parlindungan Tambunan M.Si yang telah membimbing penulisan artikel ini hingga selesai.

\section{Daftar Pustaka}

Ahmad, F., Arifin, H. S., \& Dahlan, E. N. (2012). Analisis Hubungan Ruang Terbuka Hijau dan Perubahan Suhu di Kota Palu. Jurnal Hutan Tropis, 13(2), 173-180.

Arifin \& Sutami. S (2014) Analisis Kebutuhan Ruang Terbuka Hijau Kecamatan Kota Tengah Kota Gorontalo. Radial. 27-31

Balqis, N., Syahadat, R. M., \& Ameliawati, P. (2018). Analisis Perubahan Indeks Kerapatan Vegetasi Dengan Metode Analisis Normalized Difference Vegetation Index (Ndvi) Di Kota Batu Berbasis Sistem Informasi Geografis (Gis) Dan Pengindraan Jauh. Mintakat: Jurnal Arsitektur, 19(2), 59-67. https://doi.org/10.26905/mintakat.v $19 i 2.2356$

BPS Kota Bekasi. (2020). Kota Bekasi dalam Angka 2020. BPS Kota Bekasi, 346. http://dx.doi.org/10.1016/j.jsames. 2011.03.003\%0A

Cahya, D. L., Widyawati, L. F., \&
Ayodhia, F. W. (2016). Evaluasi ketersediaan ruang terbuka hijau di Kota Bekasi. Jurnal Planesa, 7(1), 1-9.

Febrianti, N., \& Sofan, P. (2014). Ruang Terbuka Hijau Di Dki Jakarta Berdasarkan Analisis Spasial Dan Spektral Data Landsat 8. Deteksi Parameter Geobiofisik Dan Diseminasi Penginderaan Jauh , Seminar Nasional Penginderaan Jauh, April, 498-504.

Hatulesila, J. W., Mardiatmoko, G., \& Irwanto. (2019). Analisis Nilai Indeks Kehijauan (Ndvi) Pada Pola Ruang Kota Ambon, Provinsi Maluku. Jurnal Hutan Pulau-Pulau Kecil, 3(1), 55-67. https://doi.org/10.30598/jhppk.201 9.3.1.55

Indraputra.A \& Hidayati I.N (2016) Pemanfaatan Citra Penginderaan Jauh untuk Pemetaan Ketersediaan Ruang Terbuka Hijau dan Tingkat Kenyamanan di Sebagian Kota Semarang. Jurnal Bumi Indonesia, 1-10.

Mantalean, V. (2020). Ruang Hijau Menipis , Wali Kota Bekasi Mengaku Akan Evaluasi Model Hunian.https://megapolitan.

diakses 5 Februari 2021 dari http://www.

kompas.com/read/2020/01/29/133

92811/ruang-hijau-menipis-walikota-bekasi-mengaku-akanevaluasi-model-hunian.html

Maysitha, M., \& Ariffin, A. (2019). Evaluasi Tingkat Kenyamanan Ruang Terbuka Hijau di Kota Bekasi (Studi Kasus: Taman Kota Bekasi). Jurnal Produksi Tanaman, 7(4), 690-697. http://protan.studentjournal.ub.ac.i d/index.php/protan/article/view/110 5

Muta'ali, L. \& Purnamasari, S. (2012). Kajian Spasial Ruang Publik Perkotaan Untuk Aktivitas 
Demonstrasi Mahasiswa di Kota Makassar. Jurnal Bumi Indonesia, 29-36.

Noviyanti, I. K., \& Roychansyah, M. S. (2019). Analisis Ketersediaan Ruang Terbuka Hijau Dengan Ndvi Menggunakan Citra Satelit Worldview 2 Di Kota Yogyakarta. Majalah Ilmiah Globe, 21(2), 63. https://doi.org/10.24895/mig.2019. 21-2.950

Pambudi, B. P., Sungkawa, D., \& Jupri. (2015). Optimalisasi pemanfaatan taman kota oleh masyarakat kota bekasi. Jurnal Gea UPI.

Peraturan Daerah Nomor 16 Tahun 2011 Tentang Penyediaan dan Penyerahan Prasarana, Sarana dan Utilitas Kawasan Perumaan, Perdagangan dan Industri oleh Pengembang di Kota Bekasi.

Phanderson, A., Herwindiati, D. E., \& Mulyawan, B. (2018). Sistem Pendeteksi Perubahan Lahan Hijau Di Jabodetabek. Computatio: Journal of Computer Science and Information Systems, 2(1), 91. https://doi.org/10.24912/computati o.v2i1.1480

Ramadhan, I. N. (2018). Analisis ketersediaan dan pemanfaatan ruang terbuka hijau perkotaan dalam meningkatkan persepsi masyarakat Kota Bekasi:Bandung. UIN Sunan Gunung Djati.

Sanjoto, T. B. (2013). Perubahan Kerapatan Vegetasi Daerah Aliran Sungai Bodri Berdasarkan Interpretasi Citra Penginderaan Jauh. Jurnal Geografi UNNES, Vol 10, 1-13.

Shani, M. F. \& Andri (2015) Kajian Keterjangkauan dan Kebutuhan Ruang Terbuka Hijau di Kawasan Perkotaan di Kota Sukabumi. Jurnal Bumi Indonesia, 1-8.

Sitanggang, G. (2011). Kajian Pemanfaatan Satelit Masa Depan: Sistem Penginderaan Jauh Satelit
LDCM (LANDSAT-8). Berita Dirgantara, 11, 47-58.

Sitorus, S. R. P., Leonataris, C., \& Panuju, D. R. (2012). Analisis Pola Perubahan Penggunaan Lahan Dan Perkembangan Wilayah Di Kota Bekasi, Provinsi Jawa Barat. Jurnal IImu Tanah Dan Lingkungan, 14(1), 21. https://doi.org/10.29244/jitl.14.1.21 $-28$

Tucker, C. J. (1979). Red and photographic infrared linear combinations for monitoring vegetation. Remote Sensing of Environment, 8, 1-24.

Undang-Undang Republik Indonesia Nomor 26 Tahun 2007 Tentang Penataan Ruang

WHO. (2016). Urban green spaces: a brief for action. 1-24.

Widiastuti,F (2012) Analisis Ruang Terbuka Hijau dan Kecukupunnya Terhadap Jumlah Penduduk di Kota Bekasi: Bogor. Intstitut Pertanian Bgor

Yunhai, C., Peijun, S., Xiaoning, L., \& Jing, C. (2006). A combined approach for estimating vegetation cover in urban/suburban environments from remotely sensed data. Computer \& Geosciences, 32. 1299-1309. 